\title{
Effect of nutrient limitation on abundance and growth of phytoplankton in a Japanese pearl farm
}

\author{
Tomoki Hashimoto ${ }^{1}$, Shin-ichi Nakano ${ }^{1,2, *}$ \\ ${ }^{1}$ Center for Marine Environmental Studies, Ehime University, Bunkyo-cho 3, Matsuyama 790-8577, Ehime, Japan \\ ${ }^{2}$ Present address: Laboratory of Aquatic Food Web Dynamics (LAFWEDY), Faculty of Agriculture, Ehime University, \\ Bunkyo-cho 3, Matsuyama 790-8577, Ehime, Japan
}

\begin{abstract}
Seasonal changes in abundance and species composition of phytoplankton were monitored monthly and bioassays to examine nitrogen, phosphorus and silica limitation on the phytoplankton were conducted simultaneously from 2000 to 2001 in a bay of the Uwa Sea where many pearl farms culture the pearl oyster Pinctada fucata martensii, whose main food is phytoplankton. Dominant phytoplankton were the diatom genera Nitzschia and Chaetoceros, and dinoflagellates dominated by Gymnodinium were also abundant. Systemic and growth rate limitations of phosphorus were found only in July 2000, suggesting that P was not an important limiting element in the bay. By contrast, systemic limitation of nitrogen was detected on 8 out of 12 occasions, while growth rate limitation was detected on 5 occasions. Systemic limitation without growth-rate limitation was found in September, November and December 2000, and April and May 2001, when nitrate concentrations were relatively high. We detected both systemic and growth-rate limitations of nitrogen on phytoplankton in June 2000, and February and March 2001, when nitrate concentrations were low. Hence, severe nutrient limitation, or deficiency, would be found if both systemic and growth rate limitations were detected simultaneously.
\end{abstract}

KEY WORDS: Phytoplankton · Nutrient limitation · Nitrogen · Phosphorus · Silica · Coastal sea

Resale or republication not permitted without written consent of the publisher

\section{INTRODUCTION}

Nixon (1995) defined the term 'eutrophication' an increase in the rate of supply of organic matter to an ecosystem. In coastal seas, elements of nitrogen and phosphorus are also simultaneously supplied, and loadings of the elements into the seas due to human activities have caused deterioration of the water quality. Howarth et al. (1996) assembled nitrogen budgets in 14 regions of watersheds flowing into the North Atlantic Ocean, and estimated total nitrogen export in all of the major rivers draining into the ocean. Gabric \& Bell (1993) summarized eutrophication and its symptoms in many coastal seas. One of the most notorious symptoms of eutrophication is massive growth of bloom-forming algae in the phytoplankton. For example, Phaeocystis blooms, due to elevated nutrient levels, have been reported in the southern North Sea
(Cadee \& Hageman 1986) and the Irish Sea (Gowen et al. 2000). Food web structure and function may depend on abundance and activity of dominant phytoplankters. It is therefore important to elucidate the mechanisms of dominance by a certain phytoplankton species.

Nutrients often have major regulatory effects on phytoplankton abundance and composition (Hecky \& Kilham 1988, Howarth et al. 1988, Fisher et al. 1995), and previous studies have demonstrated that nitrogen (Ryther \& Dunstan 1971, Twomey \& Thompson 2001), phosphorus (Chaudani \& Vighi 1982, Holmboe et al. 1999, Diaz et al. 2001, Yin et al. 2001,) or silica (Egge \& Aksnes 1992, Del Amo et al. 1997) may limit phytoplankton abundance and determine the dominant phytoplankters. Ratios of the elements are particularly important (Hecky \& Kilham 1988, Howarth et al. 1988). For example, decreases in $\mathrm{Si}: \mathrm{N}$ ratios of coastal seas 
due to decreases in the supply of silicate caused by dam construction, or increases in nitrogen supply from waste discharge, may impose Si limitation on phytoplankton in coastal seas and a shift of the dominant phytoplankton from diatoms to flagellates (Billen et al. 1991, Humborg et al. 1997). Riegman et al. (1992) noted that not only elevated nutrient levels but also shifts in nutrient ratios were the reasons for Phaeocystis blooms in the southern North Sea. Limiting nutrients determining dominant phytoplankters may vary, depending on each system. Hence, the limiting nutrients should be examined in each coastal sea.

The Uwa Sea is a Japanese coastal sea to the west of Shikoku Island (Fig. 1). Its trophic status is variable due to water intrusions, but is normally oligotrophic (Kawabata \& Satake 1992, Koizumi \& Kohno 1992, Koizumi et al. 1997). Also, the sea is the largest and most productive area in Japan used for cultivation of the pearl oyster Pinctada fucata martensii. This oyster is a suspension feeders whose main food is phytoplankton. It has been shown that diatoms of appropriate sizes and have high nutritional value for adult oyster growth may be their most important food (Sawano 1950, Ohta 1959, Kuwatani 1965), although some diatom species such as Nitzschia and Coscinodiscus are inappropriate (Numaguchi 1996). Thus, to clarify which elements may limit the abundance and growth of phytoplankton, and which phytoplankters dominate in relation to nutrient supply, is important in this sea, not only from theoretical (food web structure and function) but also from practical (fisheries and eutrophication management) points of view.

In the present study, we followed seasonal changes in the abundance and species composition of phytoplankton in a bay of the Uwa Sea and simultaneously conducted nutrient enrichment bioassays to determine nitrogen, phosphorus and silica limitation on abundance and growth rate of the phytoplankton. In previ-

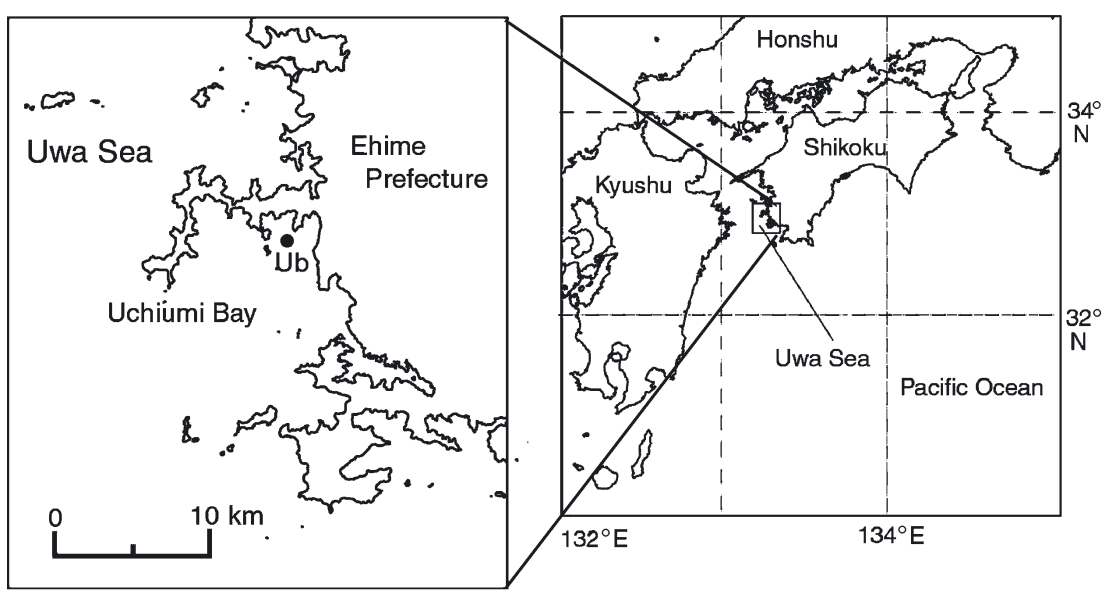

Fig. 1. Location of the study site and station (Stn Ub, •) ous bioassays using community cultures of coastal phytoplankton assemblages, results have been separately analyzed based on abundance, growth rate, primary production, enzymatic activity or tracer uptake (Hecky \& Kilham 1988, Fisher et al. 1995). Hence, the present study examined the synergistic estimation of limiting nutrients using abundance and growth rate of phytoplankton.

\section{MATERIALS AND METHODS}

The present study was conducted in Uchiumi Bay, which is used as a pearl farm (Fig. 1). There is no inflowing river or stream into the bay. The monthly monitoring was conducted at the Ub station $\left(33^{\circ} 2^{\prime} \mathrm{N}\right.$, $132^{\circ} 28^{\prime} \mathrm{E}_{\text {; }}$ ca. $53 \mathrm{~m}$ ) (Fig. 1), from May 2000 to May 2001. Water temperature was vertically determined using a Chlorotech profiler (Alec Electronics, ACL208-DK), and a 9.21 water sample was collected from $2 \mathrm{~m}$ depth with a 61 Van-Dorn water sampler.

In order to measure the chlorophyll concentration, 200 to $400 \mathrm{ml}$ of each water sample was filtered through a $0.2 \mu \mathrm{m}$ Nuclepore filter to retain seston. The filter was placed in a glass test tube and $6.5 \mathrm{ml}$ of $N_{1} N$ dimethylformamide was added to extract the chlorophyll, the quantity of which was then determined by the fluorometric method (Moran \& Porath 1980). A $500 \mathrm{ml}$ portion of the water sample was fixed with acid Lugol's solution at a final concentration of $1 \%$, and phytoplankton were concentrated by natural sedimentation. Phytoplankton cells were enumerated with a Fuchs-Rosenthal type haemocytometer under a microscope at $200 \times$ or $400 \times$ magnification. At least 3 aliquots were counted.

A $100 \mathrm{ml}$ portion of the water sample was filtered through a $0.2 \mu \mathrm{m}$ filter (Millipore), and the filtrate was used for chemical analyses of nutrients. The dominant form of nitrogen at $2 \mathrm{~m}$ depth was nitrate, and levels of ammonium and nitrite were negligible relative to nitrate (data not shown). Concentrations of nitrate nitrogen were determined using HPLC (Matsui et al. 1997). The concentration of dissolved inorganic phosphate (DIP) was determined by the method of Murphy \& Riley (1962).

To examine which element limited the abundance and growth rate of phytoplankton in the bay, we conducted bioassays from June 2000 to May 2001. An 8.21 portion of the water sample was filtered through a $200 \mu \mathrm{m}$ mesh plankton net (NXX 7) to remove $>200 \mu \mathrm{m}$ zooplankton before $500 \mathrm{ml}$ aliquots of the 
filtrate were then poured into $16 \times 500 \mathrm{ml}$ polycarbonate bottles. The nutrients used were $\mathrm{NH}_{4} \mathrm{Cl}(\mathrm{N})$, $\mathrm{NaH}_{2} \mathrm{PO}_{4} \cdot 12 \mathrm{H}_{2} \mathrm{O}(\mathrm{P})$ and $\mathrm{Na}_{2} \mathrm{SiO}_{3} \cdot 9 \mathrm{H}_{2} \mathrm{O}$ (Si) at final concentrations of 30,2 and $30 \mu \mathrm{mol}$ element $\mathrm{I}^{-1}$, respectively, and a single supplement of 1 nutrient was added to each of 2 bottles. Mixed supplements were also used: $\mathrm{N}+\mathrm{P}, \mathrm{N}+\mathrm{Si}, \mathrm{P}+\mathrm{Si}$ and $\mathrm{N}+\mathrm{P}+\mathrm{Si}$ added to duplicate bottles. The remaining 2 bottles served as the control. The 16 bottles thus prepared were incubated at $2 \mathrm{~m}$ depth near the shore of Uchiumi Bay. Chlorophyll concentration on Day 0 was determined using $200 \mathrm{ml}$ portions of the $200 \mu \mathrm{m}$ plankton net filtrate, and chlorophyll concentration in the bottles was followed over 1 wk using 30 to $100 \mathrm{ml}$ subsamples taken every day.

In the bioassays, we also examined nutrient limitation on abundance and growth rate of phytoplankton using chlorophyll concentration. Ratios of the maximum chlorophyll concentrations $\left(R_{\mathrm{chl}}\right)$ between the control and nutrient supplemented systems were calculated as follows: $R_{\mathrm{chl}}=C_{\text {nut }} / C_{\mathrm{ctrl}}$, where $C_{\text {nut }}$ and $C_{\mathrm{ctrl}}$ are the maximum chlorophyll concentrations in the nutrient supplement bottles and the control bottles, respectively. Growth rate of the phytoplankton was also calculated from changes in chlorophyll concentration: $\mu=\left(\ln C_{t}-\ln C_{0}\right) / t$, where $\mu$ is growth rate of phytoplankton; $C_{0}$ and $C_{\mathrm{t}}$ are chlorophyll concentrations at Day 0 and time $t(\mathrm{~d})$. We determined ratios of growth rates $\left(R_{\text {gro }}\right)$ between the control and nutrient supplement systems as follows: $R_{\text {gro }}=\mu_{\text {nut }} / \mu_{\text {ctrl }}$, where $\mu_{\text {nut }}$ and $\mu_{\text {ctrl }}$ are the growth rates in the nutrient supplement and control systems, respectively. In the systems with a single supplement of each nutrient, the one with the largest ratio greater than 1.1 was regarded as the limiting element (Table 1).

\section{RESULTS}

The water column at the station was thermally stratified from May to September 2000, vertically isothermal from October to April 2001, and again thermally stratified from May 2001 (Fig. 2A).

Nitrate concentrations (Fig. 2B) were relatively high in June and between September and December 2000 (5.0 to $9.8 \mu \mathrm{mol} \mathrm{N}^{-1}$ ), while those between January and March remained low $\left(<2.0 \mu \mathrm{mol} \mathrm{N}{ }^{-1}\right)$. In the summer of 2000, the frequency of the bottom intrusion,

Table 1. Ratio between control and nutrient supplement systems for maximum chlorophyll concentration (systemic limitation) and

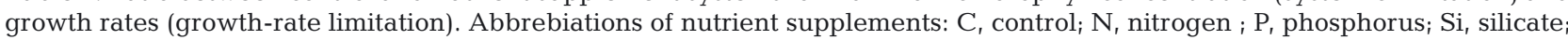
$\mathrm{N}+\mathrm{P}$, nitrogen and phosphorus; $\mathrm{N}+\mathrm{Si}$, nitrogen and silicate; $\mathrm{P}+\mathrm{Si}$, phosphorus and silicate; ALL: all the nutrients. In the 'Limitation' column, for the systems with single supplement of each nutrient, the largest ratio higher than 1.1 was regarded as the limiting element. ND: not determined

\begin{tabular}{|c|c|c|c|c|c|c|c|c|}
\hline & $\mathrm{N} / \mathrm{C}$ & $\mathrm{P} / \mathrm{C}$ & $\mathrm{Si} / \mathrm{C}$ & $\mathrm{N}+\mathrm{P} / \mathrm{C}$ & $\mathrm{N}+\mathrm{Si} / \mathrm{C}$ & $\mathrm{P}+\mathrm{Si} / \mathrm{C}$ & ALL & Limitation \\
\hline \multicolumn{9}{|l|}{ Systemic limitation } \\
\hline June 2000 & 1.6 & 0.9 & 1.0 & 6.3 & 2.6 & 1.3 & 11.1 & $\mathrm{~N}$ \\
\hline July 2000 & 0.8 & 3.0 & 0.9 & 6.7 & 0.9 & 2.8 & 12.4 & $\mathrm{P}$ \\
\hline August 2000 & 0.9 & 0.9 & 0.9 & 4.1 & 1.1 & 0.9 & 8.0 & ND \\
\hline September 2000 & 1.4 & 1.1 & 1.1 & 5.5 & 1.7 & 1.3 & 6.3 & $\mathrm{~N}$ \\
\hline October 2000 & 0.8 & 1.0 & 0.9 & 0.9 & 0.8 & 1.0 & 0.9 & ND \\
\hline November 2000 & 1.5 & 0.9 & 1.0 & 4.2 & 1.4 & 1.0 & 3.8 & $\mathrm{~N}$ \\
\hline December 2000 & 1.8 & 1.4 & 1.5 & 2.8 & 2.3 & 2.1 & 3.6 & $\mathrm{~N}$ \\
\hline January 2001 & 1.0 & 1.0 & 1.2 & 1.4 & 1.2 & 1.1 & 1.3 & $\mathrm{Si}$ \\
\hline February 2001 & 1.5 & 1.1 & 1.1 & 6.2 & 1.5 & 1.0 & 8.3 & $\mathrm{~N}$ \\
\hline March 2001 & 1.4 & 0.7 & 0.9 & 2.4 & 1.5 & 0.8 & 3.1 & $\mathrm{~N}$ \\
\hline April 2001 & 1.6 & 0.8 & 0.6 & 2.1 & 1.1 & 0.7 & 1.9 & $\mathrm{~N}$ \\
\hline May 2001 & 1.4 & 0.9 & 1.1 & 2.9 & 1.4 & 1.1 & 4.3 & $\mathrm{~N}$ \\
\hline \multicolumn{9}{|c|}{ Growth rate limitation } \\
\hline June 2000 & 2.3 & 0.2 & 0.7 & 10.5 & 3.0 & 1.3 & 14.6 & $\mathrm{~N}$ \\
\hline July 2000 & 0.9 & 2.6 & 0.7 & 2.4 & 0.6 & 2.7 & 2.5 & $\mathrm{P}$ \\
\hline August 2000 & 1.9 & 0.4 & 0.9 & 4.1 & 2.1 & 0.6 & 4.9 & $\mathrm{~N}$ \\
\hline September 2000 & 1.0 & 1.1 & 1.2 & 1.5 & 1.2 & 1.3 & 1.4 & $\mathrm{Si}$ \\
\hline October 2000 & 1.0 & 0.9 & 0.4 & 0.8 & 1.5 & 3.0 & 1.0 & ND \\
\hline November 2000 & 1.0 & 0.9 & 0.9 & 1.2 & 1.1 & 0.9 & 1.1 & ND \\
\hline December 2000 & 1.0 & 0.9 & 1.0 & 1.0 & 1.0 & 1.1 & 1.0 & ND \\
\hline January 2001 & 0.3 & 1.0 & 1.5 & 1.0 & 0.7 & 0.9 & 0.6 & $\mathrm{Si}$ \\
\hline February 2001 & 1.7 & 0.9 & 1.2 & 2.4 & 1.3 & 0.6 & 2.5 & $\mathrm{~N}$ \\
\hline March 2001 & 1.5 & 0.4 & 0.7 & 1.3 & 0.9 & 0.7 & 1.4 & $\mathrm{~N}$ \\
\hline April 2001 & 1.0 & 1.0 & 0.9 & 0.9 & 0.8 & 0.9 & 0.8 & ND \\
\hline May 2001 & 1.2 & 1.3 & 1.2 & 2.3 & 1.1 & 1.1 & 1.9 & $\mathrm{P}$ \\
\hline
\end{tabular}



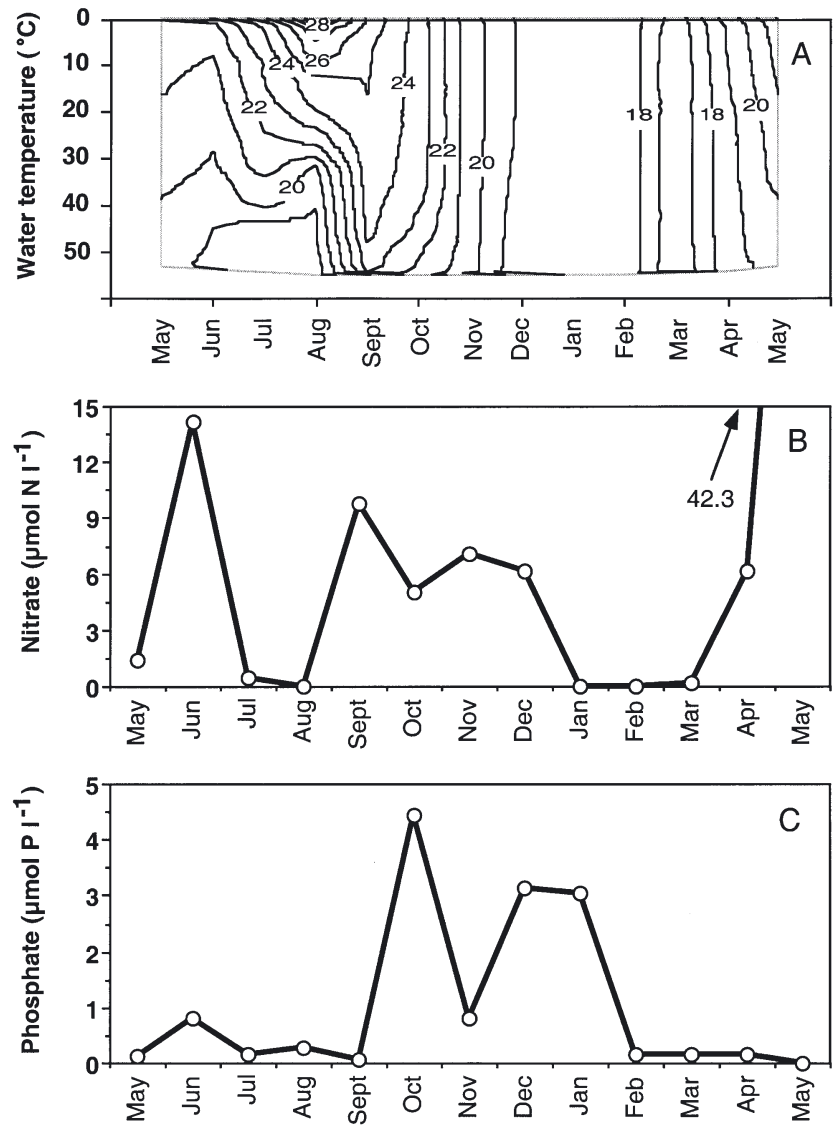

Fig. 2. Seasonal changes in (A) vertical profiles of water temperature, (B) concentrations of nitrate and (C) phosphate at $2 \mathrm{~m}$ depth in Uchiumi Bay, Japan

which is where deep, cold water slips through just above the continental shelf and is a major nutrient supply in the Uwa Sea (Takeoka et al. 2000), was higher than in average years (H. Takeoka pers. comm.), and there were blooms of red-tide dinoflagellates such as Chattonella and Gymnodinium in another bay of the Uwa Sea (S. Nakano unpubl.). In the present study, the high nitrate concentrations detected were probably due to nutrient supplies from the bottom intrusion (H. Takeoka pers. comm.). An unusually high nitrate concentration $\left(42.3 \mu \mathrm{mol} \mathrm{N} \mathrm{l}{ }^{-1}\right)$ was detected in May 2001, probably due to nitrate input from heavy rainfall.

The seasonally changing pattern of DIP was clear (Fig. 2C) relative to that of the nitrate concentration (Fig. 2B). High phosphate concentrations remained between October 2000 and January 2001, except in November $\left(0.9 \mu \mathrm{mol} \mathrm{P}^{-1}\right)$, and phosphate concentrations in all other months were lower than $0.9 \mu \mathrm{mol} \mathrm{P} \mathrm{l}^{-1}$.

Chlorophyll concentration fluctuated with a maximum of $4.7 \mu \mathrm{g} \mathrm{l}^{-1}$ in May 2001 (Fig. 3A). The dominant phytoplankters throughout the study period were the diatoms Nitzschia spp. (Fig. 3B) and Chaetoceros spp. (Fig. 3C), although dinoflagellates (Fig. 3D), dominated by Gymnodinium sp., were also abundant in August 2000 and May 2001. Other abundant phytoplankton taxa are as follows: Prorocentrum (Dinophyceae) in August 2000, Stephanopyxis (Bacillariophyceae) in November 2000, Thalassionema (Bacillariophyceae) in November and December 2000, Rhizosolenia (Bacillariophyceae) in December 2000 and May 2001, Eucampia (Bacillariophyceae) in February 2001, Thalassiosira (Bacillariophyceae) in February 2001, Leptocylindrus (Bacillariophyceae) and Lauderia (Bacillariophyceae) in May 2001.
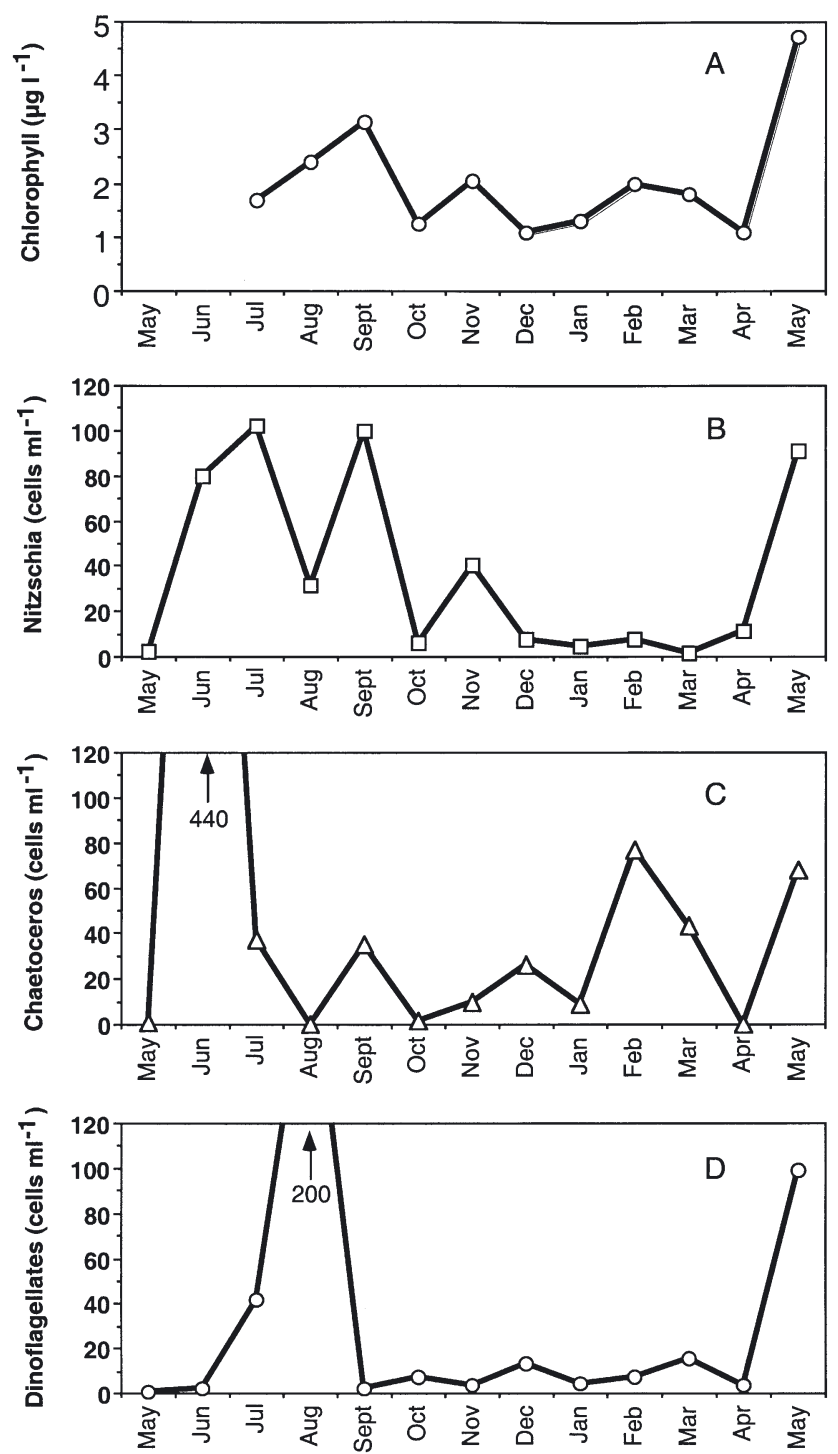

Fig. 3. Seasonal changes in (A) chlorophyll concentration and cell densities of (B) Nitzschia spp., (C) Chaetoceros spp. and (D) dinoflagellates at $2 \mathrm{~m}$ depth in Uchiumi Bay, Japan 
In the bioassays analyzed by the ratios between controls and nutrient supplement systems for maximum chlorophyll concentration, nitrogen addition enhanced phytoplankton growth on 8 of the 12 dates (Fig. 4A, Table 1), suggesting nitrogen limitation. Phosphorus limitation was obvious only in July 2000, though it was suggested in 4 cases (Fig. 4A, Table 1). Silica limitation was suggested in January 2001 (Fig. 4A, Table 1). More enhanced growth was detected in the bottle given a combined supplement of nitrogen and phosphorus (Fig. 4B, Table 1).

In the bioassays analyzed by the ratios for phytoplankton growth rate, only 4 cases of nitrogen limitation were found, phosphorus limitation was again clear in July 2000, and silica limitation was detected in
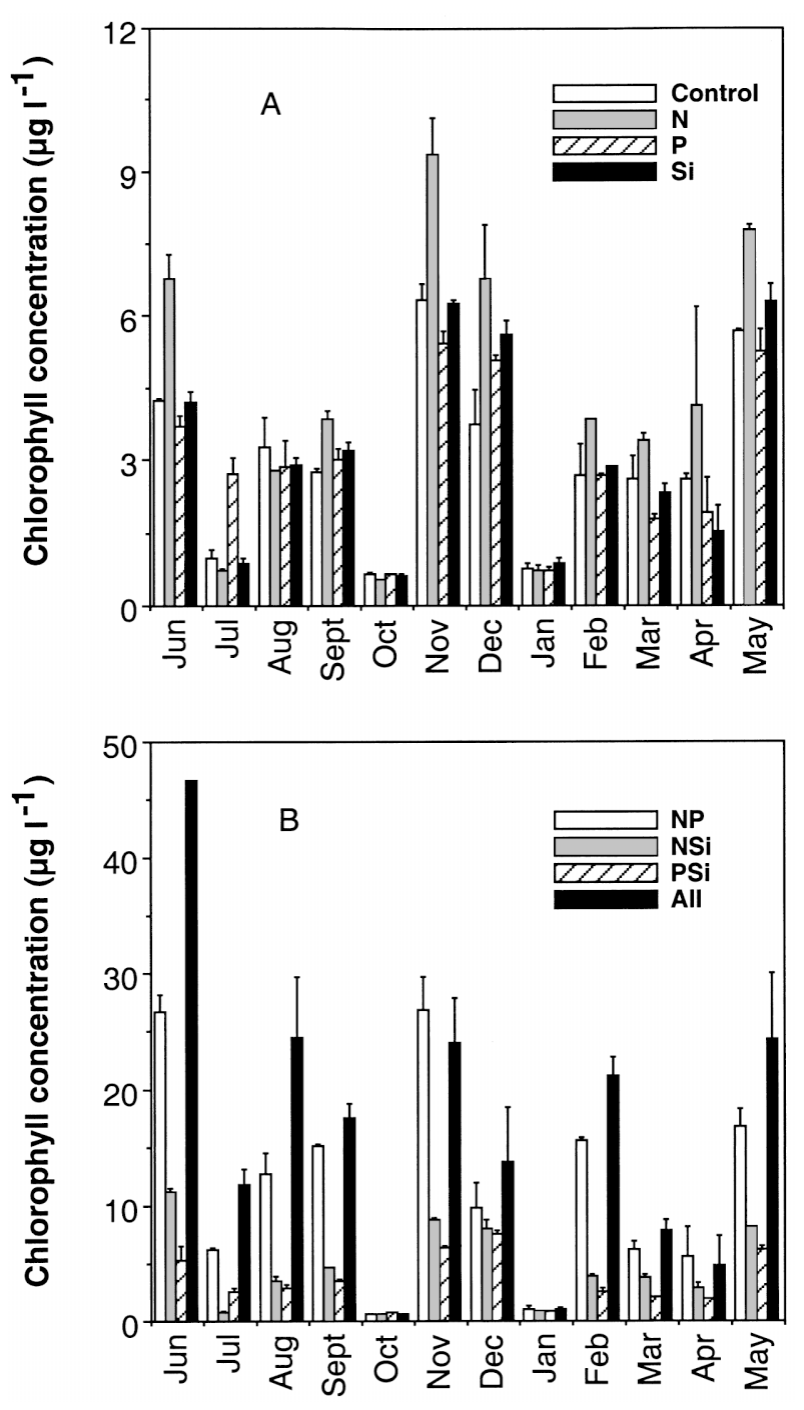

Fig. 4. Concentrations of chlorophyll in bottles enriched with nutrients and controls. Vertical bars indicate a difference between duplicates
September 2000 and January 2001 (Fig. 5A, Table 1). The effects of the combined nutrient supplements were not clear from examination of the phytoplankton growth rates (Fig. 5B, Table 1), in contrast to those evident from the maximum chlorophyll concentrations (Fig. 4B, Table 1).

\section{DISCUSSION}

There are 2 types of nutrient limitation: systemic and growth rate limitations. Fig. 6 shows a schematic expression of the result of the nutrient supplement experiment. Phytoplankton abundance would reach $\mathrm{N}_{1}$ in the control system, while phytoplankton in the
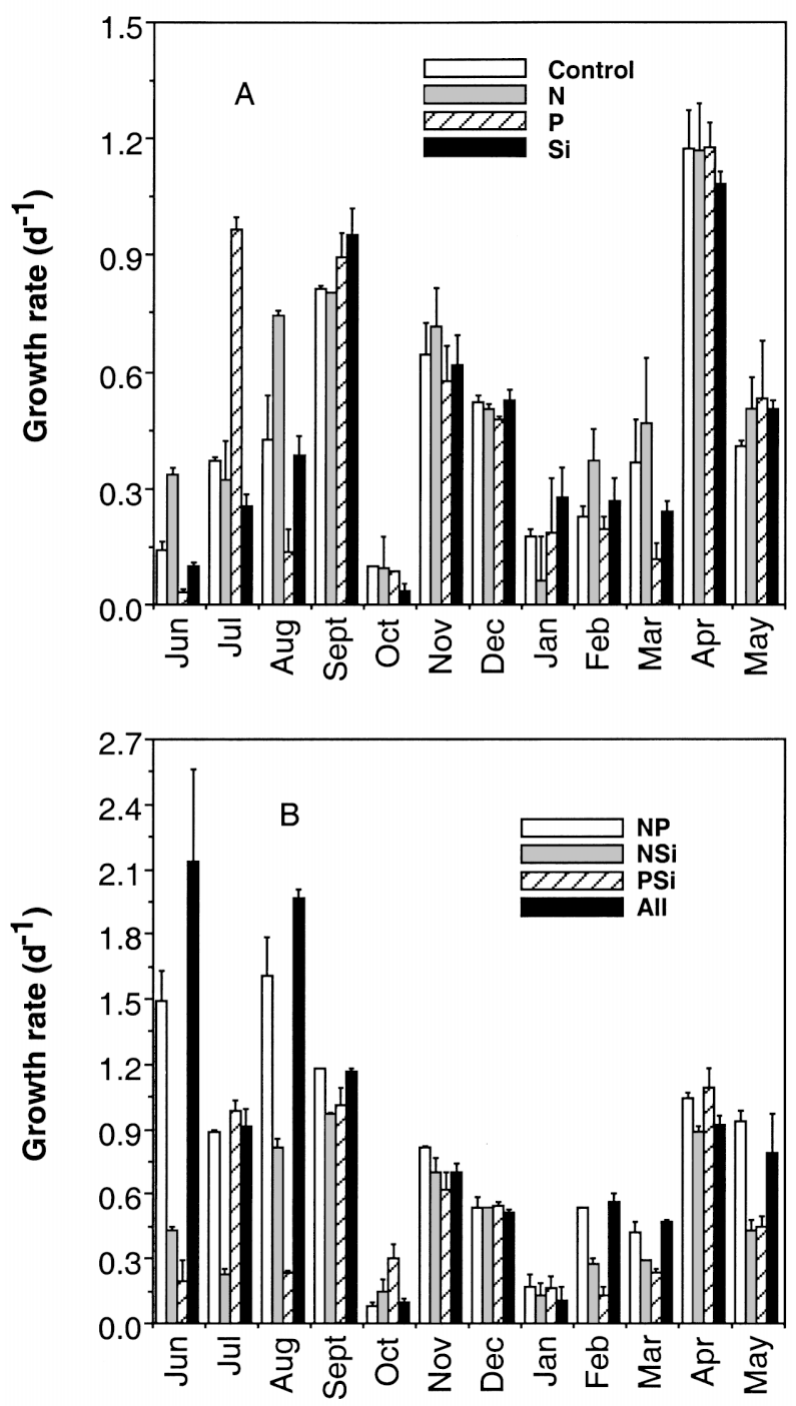

Fig. 5. Growth rates of phytoplankton in bottles enriched with nutrients and controls. Vertical bars indicate difference between duplicates 


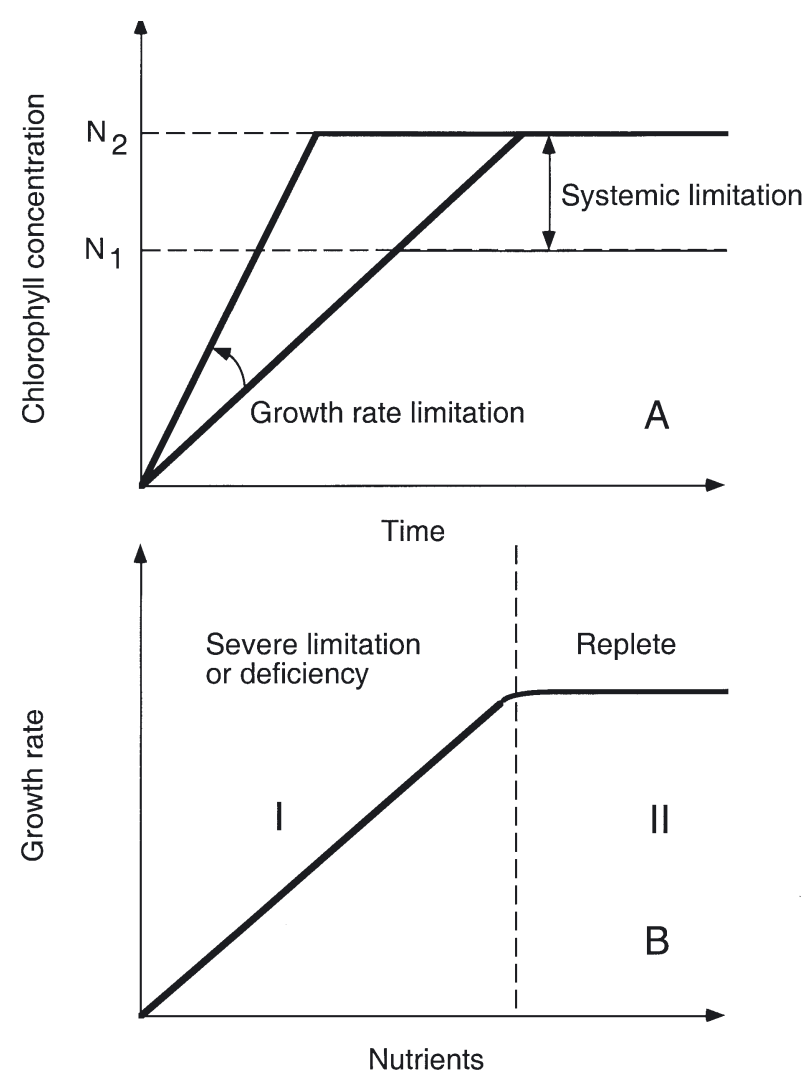

Fig. 6. Simplified diagrams of (A) systemic and growth-rate limitations for phytoplankton and (B) a Monod type relationship between phytoplankton growth rate and nutrient availability. Phytoplankton abundance would reach $\mathrm{N}_{1}$ in the control system, while phytoplankton in the nutrient supplement system would reach a higher abundance $\left(\mathrm{N}_{2}\right)$. In the Monod type relationship (B), phytoplankton under nutrient limitation are in Phase I, while Phase II indicate that phytoplankton are under nutrient replete conditions

nutrient supplement system would reach a higher abundance $\left(\mathrm{N}_{2}\right)$. This suggests systemic limitation on phytoplankton growth (Paasche \& Erga 1988, Cullen 1991). In contrast, a higher growth rate would be detected in the nutrient supplement system than in the control, suggesting growth-rate limitation (Goldman et al. 1979, Paasche \& Erga 1988). In the Monod type relationship between nutrient availability and population growth rate, if phytoplankon under nutrient limitation are in Phase I (Fig. 6), the population growth rate of phytoplankton in this phase would be stimulated when a limiting element is supplied. In this case, if it is under grazer-free conditions, the maximum abundance of phytoplankton would also become higher after supplementation of a limiting nutrient. Hence, in the present study we expected both phytoplankton growth rates and maximum chlorophyll concentrations in the nutrient supplement systems to be higher than those in the control. However, systemic limitation was more frequently detected than growth rate limitation (Table 1) in the present study. In systemic limitation, the maximum abundance of phytoplankton would become higher with supplementation of limiting nutrients, while the growth rate would be constant (Fig. 6). Thus, this case is possible when the growth rate of phytoplankton is saturated at the ambient nutrient concentration (Fig. 6). In the present study, if we consider nitrogen limitation, systemic limitation without growth-rate limitation was found in September, November and December 2000, and April and May 2001 (Table 1). This result suggests that the nutrient levels in those months were sufficient for phytoplankton growth. Indeed, nitrate concentrations were relatively high in these months (Fig. 2A). Thus, it is likely that the phytoplankton of Uchiumi Bay in those months was subjected mainly to Liebig-type systemic limitation, since there was plenty of nitrate for them in the ambient water. Furthermore, we detected both systemic and growth-rate limitations of nitrogen on the phytoplankton in June 2000, and February and March 2001 (Table 1), and nitrate concentrations in these months were also low (Fig. 2A). For phosphorus, both systemic and growth-rate limitations were found in July 2000 (Figs. 4 \& 5) when the DIP concentration was low (Fig. 2C). Hence, severe nutrient limitation or deficiency should be found when both systemic and growth-rate limitations are detected simultaneously, while phytoplankton are under moderate nutrient limitation in the case where only systemic limitation is detected. For silica limitation, both systemic and growth rate limitations were detected in January 2001 (Figs. 4 \& 5, Table 1), suggesting severe nutrient limitation or deficiency of silica on phytoplankton. Unfortunately, we cannot examine the results together with seasonal changes in silicate concentration, we did not determine silicate concentration in the present study.

The seasonal changes in the dominant phytoplankton (Fig. 3) were different from those of the nutrients, and seemed to be independent of seasonal changes in limiting elements (Table 1). Since, as mentioned above, the phytoplankton in Uchiumi Bay are mainly subjected to systemic limitation (Table 1), which indicates moderate nutrient limitation, the results shown in Fig. 3 and Table 1 are reasonable. Hence, we had to examine another environmental variable which may control phytoplankton succession at the study site. During the period of thermal stratification from May to September (Fig. 2A), high cell densities of Nitzschia (Fig. 3A) were detected, and cell densities of dinoflagellates (Fig. 3C) increased from May 2000, reaching their maximum in August 2000. It is likely that the growth of the dinoflagellates partly depended on water temperature. One might think that thermal strat- 
ification is favorable to the growth of Nitzschia. However, it is well known that diatoms become dominant in a well-mixed water column (Reynolds 1993, 1994). In another monitoring, we found that high abundance of Nitzschia distributed in the surface mixing layer of Uwa Sea during thermal stratification (T. Hashimoto \& S. Nakano unpubl.). Thus, the high abundance of Nitzschia during the thermal stratification period in the present study was probably limited within the surface mixing layer. By contrast, the diatom did not dominate (Fig. 3A) during the destratified period of October 2000 to March 2001 (Fig. 2A), although the water column during the period was mixed at $2 \mathrm{~m}$ depth as well as that of the stratified period (Fig. 2A). Hence, it is likely that the growth of Nitzschia during the stratified period was also partly due to the increase in water temperature. The light environment is also one of the most important factors affecting phytoplankton ecology. Unfortunately, we did not determine light intensity in a water column in the present study. Studies on the relationship between vertical distribution of dominant phytoplankters and the light environment should be conducted in future.

The main food of Pinctada fucata martensii is microzooplankton, meroplankton and some species of large copepoda are also eaten (Ohta 1959). The size of edible food for the adult pearl oyster is between 2.5 (Kuwatani 1965) and $360 \mu \mathrm{m}$ (Ohta 1959), and it has been reported that the main phytoplankton eaten are diatoms such as Chaetoceros, Leptocylindrus, Rhizosolenia and Skeletonema (Fukushima 1970, 1972). The diatom Nitzschia is indigestible for this oyster, although it can be ingested (Numaguchi 1996). Thus, the mortality of the oyster increases when Nitzschia dominates for a long period in the culture area (Fukushima 1970, 1972, Tomaru et al. 2001, 2002). In the present study, high densities of Nitzschia were detected in June, July and September 2000 and May 2001 (Fig. 3A), which suggests that the food environment was not favorable for the pearl oyster in the bay in those months. In Uchiumi Bay, mass mortalities of $P$. fucata martensii have occurred almost every year since 1994, and pathological investigations have been conducted to determine the cause (Suzuki et al. 1998, Kurokawa et al. 1999, Miyazaki et al. 1999). However, the physiological condition of the oyster would also be affected by food limitation. Tomaru et al. (2001) hypothesized that $P$. fucata martensii was weakened by starvation because of the dominance of inedible food such as Nitzschia, and that it then contracted an infectious disease resulting in mortality.

In the present study, we have successfully demonstrated systemic and growth rate limitations on the phytoplankton in relation to external nutrient levels, using the Monod type equation of numerical response.
However, the succession of dominant phytoplankton species could not be explained by seasonal changes in the levels of limiting elements and nutrients. Water temperature is one of the important environmental factors determining phytoplankton succession, and factors such as mixing condition and grazing pressure remain to be examined. Further studies on the ecology of phytoplankton are also needed for better management of the pearl oyster cultivation in Uchiumi Bay.

Acknowledgements. We dedicate the present article to Mr. Masuhiro Hashimoto, who supported T.H. with endless understanding. We are grateful to T. Hirose, K. Hyodo and other staff of the Uchiumi Institute of Oceanic and Fishery Science for their help in field sampling. Thanks are also due to M. Miyagaki, M. Hirose, Y. Hotta, H. Ueno, D. Ichinotsuka and the members of the Marine Molecular Ecology Laboratory, Ehime University for their advice, discussions and encouragement throughout the study. We also thank Dr. T. Katano for valuable discussions, Prof. K. Ohmori for chemical analysis and Dr. M. Morris for her correction of English and constructive comments on an earlier version of the manuscript. This study was partly supported by a Japan Society for the Promotion of Science, Grant-in-Aid for Scientific Research (A) Project No. 12308027.

\section{LITERATURE CITED}

Billen G, Lancelot C, Maybeck M (1991) N, P, Si retention along the aquatic continuum from land to ocean. In: Matoura RFC, Martin JM, Wollast R (eds) Ocean margin processes in global change. John Wiley \& Sons, New York, p $19-44$

Cadee GC, Hageman J (1986) Seasonal and annual variation in Phaeocystis pochetii (Haptophyceae) in the westernmost inlet of the Wadden Sea during 1973 to 1985 period. Neth J Sea Res 20:29-36

Chiaudani G, Vighi M (1982) Multistep approach to identification of limiting nutrients in Northern Adriatic eutrophied coastal waters. Water Res 16:1161-1166

Cullen JJ (1991) Hypothesis to explain high-nutrient conditions in the open sea. Limnol Oceanogr 36:1578-1599

Del Amo Y, Pape OL, Treguer P, Queguiner B, Menesguen A, Aminot A (1997) Impacts of high-nitrate freshwater inputs on macrotidal ecosystems. I. Seasonal evolution of nutrient limitation for the diatom-dominated phytoplankton of the Bay of Brest (France). Mar Ecol Prog Ser 161:213-224

Diaz F, Raimbault P, Boudjellal B, Garcia N, Moutin T (2001) Early spring phosphorus limitation of primary productivity in a NW Mediterranean coastal zone (Gulf of Lions). Mar Ecol Prog Ser 211:51-62

Egge JK, Aksnes DL (1992) Silicate as regulating nutrient in phytoplankton competition. Mar Ecol Prog Ser 83:281-289

Fisher TR, Melack JM, Grobbelaar JU, Howarth RW (1995) Nutrient limitation of phytoplankton and eutrophication of inland, estuarine, and marine waters. In: Tiessen H (ed) Phosphorus in the global environment. SCOPE, John Wiley \& Sons, New York, p 331-322

Fukushima K (1970) Mass mortalities of Japanese pearl oyster Pinctada fucata martensii in Matoya Bay and Gokasho Bay. Shinjugijutsu-Kenkyukai-Kaiho 9:1-21 (in Japanese)

Fukushima K (1972) The health of Pinctada fucata martensii and food organisms environment. ShinjugijutsuKenkyukai Kaiho 10:15-31 (in Japanese) 
Gabric AJ, Bell PRF (1993) Review of the effects of non-point nutrient loading on coastal ecosystems. Aust J Mar Freshw Res 44:261-283

Goldman JC, McCarthy JJ, Peavey DG (1979) Growth rate influence on the chemical composition of phytoplankton in oceanic waters. Nature 279:210-215

Gowen RJ, Mills DK, Trimmer M, Nedwell DB (2000) Production and its fate in two coastal regions of the Irish Sea: the influence of anthropogenic nutrients. Mar Ecol Prog Ser 208:51-64

Hecky RE, Kilham P (1988) Nutrient limitation of phytoplankton in freshwater and marine environments: a review of recent evidence on the effects of enrichment. Limnol Oceanogr 33:796-82

Holmboe N, Jensen HS, Andersen FO (1999) Nutrient addition bioassays as indicators of nutrient limitation of phytoplankton in an eutrophic estuary. Mar Ecol Prog Ser 186: 95-104

Howarth RW, Marino R, Cole JJ (1988) Nitrogen fixation in freshwater, estuarine, and marine ecosystems. 2. Biogeochemical controls. Limnol Oceanogr 33:688-701

Howarth RW, Billen G, Swaney D, Townsend A and 11 others (1996) Regional nitrogen budgets and riverine $N$ \& $P$ fluxes from the drainages to the North Atlantic Ocean: natural and human influences. Biogeochemistry 35:75-139

Humborg C, Ittekkot V, Cociasu A, Bodungen BV (1997) Effect of Danube River dam on Black Sea biogeochemistry and ecosystem structure. Nature 386:385-388

Kawabata Z, Satake M (1992) Changes in water movement, nutrient concentrations and phytoplankton biomass caused by the kyucho in a bay. Engankaiyou Kenkyu Note 30: 27-36 (in Japanese with English abstract)

Koizumi Y, Kohno Y (1994) An influence of the kyucho on a mechanism of diatom growth in Shitaba Bay in summer. Engankaiyou Kenkyu Note 32:81-89 (in Japanese with English abstract)

Koizumi Y, Nishikawa S, Yakushiji F, Uchida T (1997) Germination of resting stage cells and growth of vegetative cells in diatoms caused by kyucho events. Suisankaiyou Kenkyuu 61:275-287 (in Japanese with English abstract)

Kurokawa H, Suzuki T, Okauchi M, Miwa S and 6 others (1999) Experimental infections of a disease causing mass mortalities of Japanese pearl oyster Pinctada fucata martensii by tissue transplantation and cohabitation. Nippon Suisan Gakkaishi 65:241-251 (in Japanese with English abstract)

Kuwatani M (1965) A study on feeding machanism of Japanese pearl oyster, Pinctada martensii (Dunker), with special reference to passage of charcoal particles in the digestive system. Bull Jpn Soc Sci Fish 31:789-798

Matsui M, Goto T, Ishibashi T, Nishikawa M (1997) Simultaneous determination of ammonia, nitrite and nitrate in the environmental samples by HPLC. J Environ Chem 7:23-30

Miyazaki T, Goto K, Kobayashi T, Kageyama T, Miyata M (1999) Mass mortalities associated with a virus disease

Editorial responsibility: Victor de Jonge (Contributing Editor), Haren, The Netherlands in Japanese pearl oysters Pinctada fucata martensii. Dis Aquat Org 37:1-12

Moran R, Porath D (1980) Chlorophyll determination in intact tissues using $N, N$-dimethylformamide. Plant Physiol 65: 478-479

Murphy J, Riley P (1962) A modified single solution method for the determination of phosphorus in natural waters. Anal Chim Acta 27:31-36

Nixon SW (1995) Coastal marine eutrophication: a definition, social causes, and future concerns. Ophelia 41:199-219

Numaguchi K (1996) A review on the feeding ecology and food environment of the Japanese pearl oyster, Pinctada fucata martensii. Bull Natl Res Inst Fish Sci 8:123-138

Ohta S (1959) Studies on feeding habits of Pinctada martensii. V. Number and size of swimming bivalve larvae fed by pearl oyster in summer. Bull Natl Pearl Res Lab 5:443-449

Paashce E, Erga SR (1988) Phosphorus and nitrogen limitation of phytoplankton in the inner Oslofjord (Norway). Sarsia 73:229-243

Riegman R, Noordeloos AAM, Cadee GC (1992) Phaeocystic blooms and eutrophication of the continental coastal zones of the North Sea. Mar Biol 112:479-484

Reynolds CS (1993) Scales of disturbance and their role in plankton ecology. Hydrobiologia 249:157-171

Reynolds CS (1994) The long, the short and the stalled: on the attributes of phytoplankton selected by physical mixing in lakes and rivers. Hydrobiologia 289:9-21

Ryther JH, Dunstan WM (1971) Nitrogen, phosphorus, and eutrophication in the coastal marine environment. Science 171:1008-1013

Sawano E (1950) Culture method study of pearl oyster in pond. Fish Mar Stud 3:48-57 (in Japanese)

Suzuki S, Kamakura M, Kusuda R (1998) Isolation of birnavirus from Japanese pearl oyster Pinctada fucata. Fish Sci 64:342-343

Takeoka H, Koizumi Y, Kaneda A (2000) Year-to-year variation of a kyucho and a bottom intrusion in the Bungo Channel, Japan. In: Yanagi $\mathrm{T}$ (ed) Interactions between estuaries, coastal seas and shelf seas. Terra Scientific Publishing, Tokyo, p 197-215

Tomaru Y, Kawabata Z, Nakano S (2001) Mass mortality of the Japanese pearl oyster Pinctada fucata martensii in relation to water temperaure, chlorophyll a and phytoplankton composition. Dis Aquat Org 44:61-68

Tomaru Y, Udaka N, Kawabata Z and Nakano S (2002) Seasonal change of seston size distribution and phytoplankton composition in bivalve pearl oyster Pinctada fucata martensii culture farm. Hydrobiologia 481:181-185

Twomey L, Thompson P (2001) Nutrient limitation of phytoplankton in a seasonally open bar-built estuary: Wilson Inlet, Western Australia. J Phycol 37:16-29

Yin K, Qian PY, Wu MCS, Chen JC, Huang L, Song X, Jian W (2001) Shift from P to N limitation of phytoplankton growth across the Pearl River estuarine plume during summer. Mar Ecol Prog Ser 221:17-28

Submitted: June 26, 2002; Accepted: May 9, 2003

Proofs received from author(s): August 21, 2003 